\title{
Comparing the effect of different levels of zinc hydroxychloride with inorganic zinc sulfate on in vitro rumen fermentation parameters
}

\author{
Ravi Prakash Pal, Veena Mani, Srobana Sarkar, Shahid Hassan Mir, Amit Sharma and Hunny Sharma
}

Received: 13 June 2020 / Accepted: 19 October 2020 / Published online: 27 December 2020

(C) Indian Dairy Association (India) 2020

\begin{abstract}
Optimum productivity in ruminants is positively related to efficient rumen fermentation. Apart from major nutrients in diet, micronutrients (trace elements and vitamin B complex) play an essential role in maintaining proper rumen function; however the effect depends on source and level of micronutrients supplementation.Therefore, present study was conducted to compare the effects of different sources of hydroxy and inorganic zinc on in vitro rumen fermentation parameters. Different levels $(0,40,80$, and $160 \mathrm{ppm})$ of $\mathrm{Zn}$ as hydroxy zinc chloride $\left(\mathrm{Zn}_{5}(\mathrm{OH})_{8} \mathrm{Cl}_{2}\right)$ and inorganic zinc sulfate $\left(\mathrm{ZnSO}_{4}\right)$ were added in substrate consisting of roughage (sugargraze fodder; a cross of sorghum and maize) and concentrate mixture in the ratio 50:50. Inclusion of $\mathrm{Zn}$ as zinc hydroxychloride and $\mathrm{ZnSO}_{4}$ at different levels showed no change in total gas $(\mathrm{mL} / \mathrm{g} \mathrm{DM})$ production. Similarly, supplementation of zinc either as zinc hydroxychloide or $\mathrm{ZnSO}_{4}$ upto160 ppm supplementation did not affect $(\mathrm{P}>0.05)$ in vitro dry matter and organic matter digestibility (\%) of the diet. Furthermore, no significant effect was observed in the $\mathrm{CH}_{4}$ $(\%, \mathrm{~mL} / 24 \mathrm{~h}$ and $\mathrm{mL} / 100 \mathrm{mg} \mathrm{DM})$ and $\mathrm{NH}_{3}-\mathrm{N}(\mathrm{mg} / \mathrm{dL})$ and individual fatty acid concentrations with variable sources and levels of $\mathrm{Zn}$ supplementation. It can be concluded from the present findings that supplementation of both hydroxy $\mathrm{Zn}$ and inorganic $\mathrm{Zn}$ up to $160 \mathrm{ppm}$ had no adverse effect on in vitro rumen fermentation. Hence, hydroxy $\mathrm{Zn}$ can be used as an alternative source of $\mathrm{Zn}$ in the diet of ruminants to conventional inorganic sources.
\end{abstract}

Animal Nutrition Division, ICAR-National Dairy Research Institute, Karnal 132 001, India

Ravi Prakash Pal ( $\square)$

Animal Nutrition Division, ICAR-National Dairy Research Institute, Karnal, 132 001, Haryana, India

E-mail address: raviprakashpa191@gmail.com, Tel: +91-8305808737
Keywords: In vitro, Rumen fermentation, Zinc hydroxy chloride, Zinc sulphate

\section{Introduction}

Increased rumen fermentation efficiency leads to improved growth and production in animals. Various micronutrients affect rumen fermentation (Rodriguez et al. 1995; Arelovich et al. 2000). Especially, trace minerals are associated with several enzyme complexes and affect metabolic utilization of major nutrients like carbohydrates and proteins. Among the trace minerals, zinc ( $\mathrm{Zn}$ ) is vital for both animals and rumen microorganism for proper metabolic functions. Irrespective of sources, $\mathrm{Zn}$ at higher concentration affects cellulytic and proteolytic activity of rumen microbes (Eryavuz and Dehority 2009; Karr et al. 1991). Feeding high levels of $\mathrm{Zn}$ in the form of zinc sulfate decresed rumen fermentation and protozoa numbers in steers (Froetschel et al. 1990). Previous research has shown that rumen microorganism require much lower doses of $\mathrm{Zn}$ than those typically present in ruminant diets (Hubbert et al. 1958; Martinez et al. 1970). However, recent studies (Nagalakshmi et al. 2016) showed that host animal require higher dose of $\mathrm{Zn}(80-140 \mathrm{ppm})$ than ICAR recommendation to improve health and immunity. Generally, trace minerals derived from feedstuffs and supplemental sources are soluble in rumen environment. Requirement of $\mathrm{Zn}$ for rumen microorganism is full filled by $\mathrm{Zn}$ present in feeds and fodders. However, solubility of trace minerals can affect the total concentration of available mineral to rumen microorganism because, only soluble minerals are available for use or interactions in rumen. Higher concentrations of soluble $\mathrm{Zn}(150 \mu \mathrm{g} / \mathrm{mL})$ in the rumen can decrease cellulose digestion (Eryavuz and Dehority, 2009). Inorganic $\mathrm{Zn}$ sources are extensively soluble in rumen environment (Spears, 2013). Recently, hydroxy trace minerals are introduced as a new source of mineral in livestock feeding as they have low solubility in water (Cao et al. 2013) and rumen $\mathrm{pH}$ than inorganic source (Shaeffer, 2006). Hydroxy trace minerals are produced by crystallization process. Due to its crystalline structure it does not dissociate at rumen $\mathrm{pH}$ thereby reducing the chances of adverse effects on digestibility and rumen fermentation at higher doses. Recently, Caldera et al. (2019) reported that $\mathrm{Zn}$ from zinc hydroxychloride $(\mathrm{ZnOHCl})$ had low rumen solubility and less tightly bound to ruminal solid digesta 
compared to $\mathrm{Zn}$ from $\mathrm{ZnSO}_{4}$. However, lesser rumen solubility of $\mathrm{Zn}$ from $\mathrm{ZnOHCl}$ may affect rumen fermentation in a different way than $\mathrm{Zn}$ available from inorganic sources. Therefore, hypothesis of the present study was that $\mathrm{Zn}$ from hydroxy source will not cause any negative effect on rumen fermentation parameters and fibre digestion compared to inorganic source and till date no research has been done to assess the effect of hydroxy $\mathrm{Zn}$ on rumen fermentation pattern.Therefore, present experiment was conducted to evaluate the effect of $\mathrm{ZnOHCl}$ supplementation on in vitro rumen fermentation parameters compared to $\mathrm{ZnSO}_{4}$.

\section{Materials and Methods}

\section{Substrate composition}

To assess the effect of supplementing different levels of $\mathrm{ZnOHCl}$ and $\mathrm{ZnSO}_{4}$, a substrate was prepared withsugargraze and concentrate in the ratio of 50:50. Four levels of $Z n$ i.e. $0,40,80$ and $160 \mathrm{ppm}$ was added in the form $\mathrm{ZnOHCl}$ and $\mathrm{ZnSO}_{4}$ was added in graded levels for assessing comparative effect on rumen fermentation and DM digestibility under in vitro conditions. Proximate principles (AOAC, 2005) and fibre fractions (Van Soest et al. 1991) were determined for concentrate mixture and sugargraze fodder.

\section{Total gas production and methane}

For estimating in vitro gas production (Menke and Steingass, 1988), rumen liquor was collected from two fistulated buffalo bulls maintained on a standard diet of $50 \%$ roughage and $50 \%$ concentrate. About $200 \pm 10 \mathrm{mg}$ of moisture free substrate containing sugargraze and concentrate mixture was incubated in glass syringes of $100 \mathrm{ml}$ capacity along with $30 \mathrm{ml}$ of buffered rumen inoculum for $24 \mathrm{~h}$ at $39 \pm 0.5^{\circ} \mathrm{C}$. After incubation, total gas production was calculated and subsequent blank corrections were made. Subsequent blank corrections were made by subtracting the amount of gas produced from incubation of syringes consisting of buffered rumen fluid without substrate for correcting gas production from fermentation of endogenous substrates. For estimation of methane $\left(\mathrm{CH}_{4}\right)$, representative gas was sampled from the headspace by an airtight syringe and injected into gas chromatograph fitted with a flame ionization detector and stainless steel column packed with Porapak-Q. A standard mixture of 50/50 methane and carbon dioxide was used for calculating the concentration of $\mathrm{CH}_{4}$ in unknown samples.

\section{In vitro dry matter digestibility and microbial biomass production}

For estimation of vitro true dry matter digestibility(IVTDMD), the pellets obtained after centrifugation of incubated samples werere fluxed with $40 \mathrm{~mL}$ of neutral detergent solution for an hour, filtered through $\mathrm{G} 1$ crucibles and residues were dried in hot air oven $\left(80^{\circ} \mathrm{C}\right)$. The loss in weight was considered as true dry matter digestibility. In vitro true organic matter digestibility (IVTOMD) was estimated by ashing the residue at $550^{\circ} \mathrm{C}$ in muffle furnace. The partitioning factor $(\mathrm{PF})$ and microbial biomass production (MBP) were calculated based on truly degraded organic matter (TDOM) as described by Blummel et al. (1999) and Blummel et al. (2005), respectively. Where, TDOM was calculated by multiplying TOMD (\%) by OM content (mg)of substrate. And PF was calculated by dividing TDOM (mg)/Net gas production $(\mathrm{mL} / 24 \mathrm{~h})$ and microbial biomass production (MBP) from TDOM using equation:MBP (mg) = TDOM (mg) (Net gas volume $\times 2.20$ ), where 2.20 is the stoichiometric factor.

\section{Individual volatile fatty acids and ammonia nitrogen}

After collectionof gas sample the contents of each syringe were centrifugedat $3000 \mathrm{rpm}$ for 15 minutes to get a clear supernatant. An aliquot of the centrifuged supernatant along with equal volumes of $33 \%$ metaphosphoric acid was preserved at $-20^{\circ} \mathrm{C}$ for determining individual volatile fatty acids ( Erwin et al. 1961) using gas chromatograph fitted to a flameionization detector and stainless steel column packed with Chromosorb-101, whereas, another aliquot was used for estimation of ammonia nitrogen $\left(\mathrm{NH}_{3}-\mathrm{N}\right)$ by Kjeldahl method (Sahoo et al. 2010).

\section{Statistical analysis}

The data of in vitro ruminal fermentation parameters was analyzed using one-way analysis of variance (ANOVA) by SPSS, 16 . In the case of significance $(P<0.05)$ among treatments, Tukey's test was used to separate means.

\section{Results and Discussion}

Chemical composition of the substrate used as substrate has been presented in Table 1. All treatments had balanced CP and $\mathrm{ME}$ content except levels and sources of $\mathrm{Zn}$. Four levels of $\mathrm{Zn}(0$, $40,80,160 \mathrm{ppm}$ ) were added in the form of $\mathrm{ZnOHCl}$ or $\mathrm{ZnSO}_{4}$. Effect of zinc hydroxychloride and $\mathrm{ZnSO}_{4}$ on in vitro digestibility, in vitro gas production, $\mathrm{pH}, \mathrm{PF}$ and $\mathrm{MBP}$ are presented in Table 2. No significant differences were observed in total gas production (IVTGP, $\mathrm{mL} / \mathrm{g} \mathrm{DM}$ ), $\mathrm{CH}_{4}(\%), \mathrm{CH}_{4}(\mathrm{~mL} / 100 \mathrm{mg} \mathrm{DM}$ ), IVDMD (\%), IVOMD (\%),PF and MBP ( $\mathrm{mg} / \mathrm{g}$ ) among treatment groups. Supplementation of hydroxy $\mathrm{Zn}$ upto $160 \mathrm{ppm}$ had no effect on $\mathrm{NH}_{3}-\mathrm{N}$ and IVFA concentration (Table 3 ) and the results were similar to $\mathrm{ZnSO}_{4}$.

No literature is available on the effect of hydroxy $\mathrm{Zn}$ on total gas production, in vitro digestibility and rumen fermentation; however, studies are available on inorganic and organic sources of zinc (Parashuramulu et al. 2013; Wang et al. 2013)

Similarly, Zaboli and Aliarabi (2013) reported that addition of 20 or $40 \mathrm{ppm} \mathrm{Zn}$ as $\mathrm{ZnO}$ and nanoZnO did not affect total gas production. Mallaki et al.(2015) also reported that $20 \mathrm{ppm} \mathrm{Zn}$ as $\mathrm{ZnSO}_{4}$ had no significant effect on gas production, however, $\mathrm{Zn}$ 
supplementation in higher forage diet (68\% forage) increased gas production (Armijo et al. 2011). In present study 50\% concentrate and $50 \%$ forage were used as a substrate. The differences observed between studies could be due to the different ratio of concentrate: forage used in the diet. Chanzanagh et al. (2018) reported that addition of nano $\mathrm{ZnO}$ up to $60 \mathrm{ppm}$ in protein sources did not affect total gas production. Contrary to our result, Parashuramulu et at.(2013) found that gas production increased with increasing $\mathrm{Zn}$ up to $150 \mathrm{ppm}$. In present experiment, total gas production was not changed due to lower solubility of hydroxy $\mathrm{Zn}$ in rumen and thereby reducing the interaction between $\mathrm{Zn}$ and rumen microbes. $\mathrm{Zn}$ sulphate also did not change gas production in rumen might be due no effect of $\mathrm{Zn}$ level used in the experiment. Methanogens are responsible for the production $\mathrm{CH}_{4}$ in animals (Hook et al. 2010). Methanogenic archaea in anaerobic condition utilize $\mathrm{CO}_{2}$ and $\mathrm{H}_{2}$ to produce $\mathrm{CH}_{4}$. Contrary to our result, at higher level of $\mathrm{nZnO}$

Table 1 Ingredient and chemical composition of the substrate

\begin{tabular}{lc}
\hline Ingredient & Dry matter basis $(\%)$ \\
\hline Dry matter & 59.11 \\
Organic matter & 90.79 \\
Crude protein & 14.40 \\
Ether extract & 3.00 \\
Total ash & 9.20 \\
Neutral detergent fiber & 43.16 \\
Acid detergent fiber & 25.46 \\
Cellulose & 13.40 \\
Hemicellulose & 17.67 \\
Zn (ppm) & 32.55 \\
\hline
\end{tabular}

Substrate; Concentrate: Sugargraze 50: 50 (nano zinc oxide) supplementation $(1000 \mu \mathrm{g} / \mathrm{g})$ reduced the enteric $\mathrm{CH}_{4}$ concentration (Sarker et al. 2018) due to inhibitory action of $\mathrm{Zn}$ on methanogens. In present experiment, no change in $\mathrm{CH}_{4}$ production might be due to no effect of addition of $\mathrm{ZnOHCl}$ and $\mathrm{ZnSO}_{4}$ (up to $160 \mathrm{ppm}$ ) on methanogens.

Armijo et al. (2011) in a study on goats also observed no differences in IVDMD when ruminal fluid was used in in vitro ruminal fermentation. Wang et al. (2013) and Kathirvelan and Balakrishnan (2008) reported decreased IVDMD after addition of $20 \mu \mathrm{g} / \mathrm{mL} \mathrm{Zn}$ from $\mathrm{Zn}$ sulfate and $10 \mathrm{mg} / \mathrm{kg} \mathrm{Zn}$ from $\mathrm{Zn}$ chloride in in- vitro cultures with forage based substrate (concentrate and roughage; 32: 68 and 0: 100). Arelovich et al. (2008) also observed that IVDMD was decreased on addition of $5,10,15$, or $20 \mathrm{mg} / \mathrm{kg}$ inorganic $\mathrm{Zn}$ in substrate containing prairie hay, which might be due negative effect of $\mathrm{Zn}$ on cellulolytic enzyme produced by rumen bacteria. Eryavuz and Dehority (2009) reported that decreased cellulose digestion with increased supplemental $\mathrm{Zn}$ (50 ppm) might be due to negative effect of $\mathrm{Zn}$ on cellulolytic enzyme produced by ruminal bacteria which leads to decreased IVDMD. In the present study, IVDMD did not change which can be due to no effect of hydroxy $\mathrm{Zn}$ addition up to $160 \mathrm{ppm}$ on rumen microbe's function as requirement of $\mathrm{Zn}$ for rumen microbe are fulfilled by $\mathrm{Zn}$ present in basal diet. There was no significant effect in PF value and MBP among treatment groups. All these parameters were comparable to that of $\mathrm{Zn}$ supplementation in the form of sulphate. PF is the ratio of substrate degraded (mg) to the volume of gas $(\mathrm{mL})$ produced (Blummel et al. 1999). Partitioning factor (PF) is a reliable determination of true degradability of the substrate, a range of 2.74 to 4.41 is indicative of efficient rumen fermentation (Sarkar et al. 2018) which is also observed in the present study.

Table 2 Effect of supplementation of zinc hydroxychloride and zinc Sulphate on in vitro fermentation of the substrate

\begin{tabular}{|c|c|c|c|c|c|c|c|c|c|}
\hline \multirow[b]{2}{*}{ Attribute } & \multicolumn{7}{|c|}{ Supplemental Zn (ppm) } & \multirow[b]{2}{*}{ SEM } & \multirow[b]{2}{*}{$P$ value } \\
\hline & $\overline{0}$ & & $\mathrm{ZnOHCl}$ & & & $\mathrm{ZnSO}_{4}$ & & & \\
\hline $\begin{array}{l}\text { Net gas } \\
(\mathrm{ml} / 24 \mathrm{~h})\end{array}$ & 38.50 & 38.33 & 37.83 & 39.17 & 37.83 & 37.17 & 37.83 & 0.28 & 0.700 \\
\hline $\begin{array}{l}\text { Total Gas } \\
(\mathrm{mL} / \mathrm{g} \mathrm{DM})\end{array}$ & 187.02 & 188.32 & 187.45 & 192.01 & 184.71 & 183.43 & 185.67 & 1.17 & 0.620 \\
\hline Methane (\%) & 32.12 & 31.48 & 31.02 & 31.72 & 31.07 & 30.90 & 32.41 & 0.24 & 0.620 \\
\hline IVDMD \% & 62.49 & 64.37 & 64.02 & 63.96 & 65.27 & 64.09 & 63.86 & 0.30 & 0.420 \\
\hline IVOMD $\%$ & 63.74 & 65.59 & 65.14 & 65.39 & 66.50 & 65.41 & 65.31 & 0.29 & 0.360 \\
\hline $\mathrm{pH}$ & 6.27 & 6.46 & 6.53 & 6.52 & 6.42 & 6.66 & 6.44 & 0.04 & 0.280 \\
\hline $\mathrm{PF}$ & 3.20 & 3.21 & 3.21 & 3.18 & 3.20 & 3.24 & 3.21 & 0.01 & 0.730 \\
\hline
\end{tabular}

Mean values with different letters in a row differ significantly $(\mathrm{P}<0.05)$,

$\mathrm{CH}_{4}$-methane, IVDMD-in vitro dry matter digestibility, IVOMD-in vitro organic matter digestibility, PF-partition factor, MBP-microbial biomass production. 
Table 3 Effect of supplementation of zinc hydroxychloride and zinc sulphate on in-vitro $\mathrm{NH}_{3}-\mathrm{N}$ and individual volatile fatty acid (IVFA) of substrate

\begin{tabular}{|c|c|c|c|c|c|c|c|c|c|}
\hline \multirow[t]{3}{*}{ Attribute } & \multicolumn{6}{|c|}{ Supplemental Zn (ppm) } & & \multirow[t]{3}{*}{ SEM } & \multirow[t]{3}{*}{$P$ value } \\
\hline & \multicolumn{3}{|c|}{$\mathrm{ZnOHCl}$} & & \multicolumn{2}{|c|}{$\mathrm{ZnSO}_{4}$} & & & \\
\hline & 40 & 80 & 160 & 40 & 80 & 160 & & & \\
\hline $\mathrm{NH}_{3}-\mathrm{N}(\mathrm{mg} / \mathrm{dL})$ & 12.83 & 12.37 & 12.13 & 12.13 & 12.60 & 11.20 & 11.67 & 0.21 & 0.480 \\
\hline Acetate $(\mathrm{C} 2), \mathrm{mM} / \mathrm{L}$ & 34.31 & 32.59 & 33.75 & 34.10 & 34.11 & 34.74 & 31.78 & 0.50 & 0.770 \\
\hline Propionate (C3), mM/L & 17.65 & 17.46 & 18.39 & 18.49 & 18.19 & 19.00 & 18.42 & 0.23 & 0.690 \\
\hline Butyrate (C4),mM/L & 9.95 & 9.89 & 10.09 & 10.01 & 10.77 & 9.14 & 10.01 & 0.22 & 0.730 \\
\hline $\mathrm{C} 2: \mathrm{C} 3$ & 1.94 & 1.87 & 1.86 & 1.85 & 1.88 & 1.83 & 1.74 & 0.04 & 0.930 \\
\hline
\end{tabular}

Mean values with different letters in a row differ significantly $(\mathrm{P}<0.05)$,

$\mathrm{NH}_{3}-\mathrm{N}$-ammonia nitrogen, $\mathrm{C} 2: \mathrm{C} 3$-acetate propionate ratio.

Ruminal $\mathrm{pH}$ mainly depends on $\mathrm{NH}_{3}-\mathrm{N}$ degradation and volatile fatty acid formation from fermented substrate. Ruminal $\mathrm{pH}$ was unaffected by different levels and sources of $\mathrm{Zn}$. Bateman et al. (2002) showed that addition of $1,350 \mathrm{mg} \mathrm{Zn/kg} \mathrm{DM} \mathrm{did} \mathrm{not} \mathrm{alter}$ $\mathrm{pH}$ in continuous cultures. Production of ammonia $\mathrm{N}$ in rumen is related to type of diet and result from breakdown of protein and non-protein sources in feed. Minimum level of $\mathrm{NH}_{3}-\mathrm{N}(\mathrm{mg} / \mathrm{dL})$ required for the growth of rumen microorganism is $5 \mathrm{mg} / \mathrm{dL}$ (Satter and Slyter, 1974). In present experiment, level of $\mathrm{NH}_{3}-\mathrm{N}(\mathrm{mg} / \mathrm{dL})$ was higher (11.20 to 12.83$)$ than the minimum requirement for growth of rumen microbes. In this study, no significant effect was observed in $\mathrm{NH}_{3}-\mathrm{N}$ levels in different treatments which indicated the balance between $\mathrm{NH}_{3}-\mathrm{N}$ produced and microbial protein synthesised. Wang et al.(2013) also reported that addition of $\mathrm{Zn}$ upto $20 \mathrm{ppm} \mu \mathrm{g} / \mathrm{mL}$ did not change $\mathrm{NH}_{3}-\mathrm{N}$ concentration.

IVFA production result from degradation of fiber and other carbohydrate is related to type of diet. Therefore, present result showed that addition of either inorganic and hydroxy $\mathrm{Zn}$ upto $160 \mathrm{ppm}$ did not change IVFAconcentration. Similarly, Zn supplementation@ 430 mg Zn/kg DM had no effect on VFA concentrations in a diet consisting of $61 \%$ concentrate and $39 \%$ chopped alfalfa hay under in vitro condition (Arelovich et al. 2008). Spears et al. (2004) supplemented $20 \mathrm{mg} \mathrm{Zn/kg} \mathrm{DM} \mathrm{from}$ inorganic and organic sources and observed increased propionate and decreased butyrate in case of $\mathrm{Zn}$ propionate compared to control and other $\mathrm{Zn}$ sources even with so low level of supplementation. Furthermore, higher dietary concentrations (1142 ppm) of inorganic $\mathrm{Zn}$ increased molar proportion of propionate (Blummel et al. 2005).

\section{Conclusions}

It was observed from the present study that $\mathrm{Zn}$ in the form of $\mathrm{ZnOHCl}$ and $\mathrm{ZnSO}_{4}$ upto $160 \mathrm{ppm}$ had no adverse effect on rumen fermentation. Results of zinc hydroxychloride is comparable to effects of zinc sulphate, however, further in vivo studies are required to be conducted to ascertain the efficacy of zinc hydroxychlorideas a possible $\mathrm{Zn}$ source supplementation in ruminants.

\section{Acknowledgments}

The authors would like to thank the staff of the Animal Nutrition Division and Cattle Yard, Karnal, India. This study was funded by Indian Council of Agricultural Research, New Delhi, India.

\section{References}

Arelovich HM, Owens FN, Horn GW, Vizcarra JA (2000) Effects of supplemental zinc and manganese on ruminal fermentation, forage intake, and digestion by cattle fed prairie hay and urea. J Anim Sci 78: 2972-2979

Arelovich, HM, Laborde, HE, Amela, MI, Torrea MB, Martínez MF (2008) Effects of dietary addition of zinc and (or) monensin on performance, rumen fermentation and digesta kinetics in beef cattle. Span J Agric 6: $362-372$

Association of Official Analytical Chemists (2005) Official methods of analysis, 18th edn. USA, Washington DC

Bateman II HG, Williams CC, Chung YH (2002) Effects of supplemental zinc in high quality diets on ruminal fermentation and degradation of urea in vitro and in vivo. The Prof Ani Sci 18: 363-367

Blummel M, Givens DI, Moss AR (2005) Comparison of methane produced by straw fed sheep in open-circuit respiration with methane predicted by fermentation characterstics measured by an in vitro gas procedure. Anim Feed Sci Technol 123: 379-390.

Blummel M, Mgomezulu R, Chen XB, Makkar HPS, Becker K, Orskov ER (1999) The modification of an in vitro gas production test to detect roughage related differences in in vivo microbial protein synthesis as estimated by the excretion of purine derivatives. J Agric Sci 133: 335-340

Caldera E, Weigel B, Kucharczyk VN, Sellins KS, ArchibequeSL, Wagner JJ, Engle TE (2019) Trace mineral source influences ruminal distribution of copper and zinc and their binding strength to ruminaldigesta. J Anim Sci 97: 1852-1864

Cao J, Henry PR, Ammerman CB, Miles RD, Littell RC (2000) Relative bioavailability of basic zinc sulfate and basic zinc chloride for chicks. J Appl Poult Res 9 513-517

Chanzanagh EG, Seifdavati J, Gheshlagh FMA, Benamar HA, Sharifi RS (2018) Effect of $\mathrm{ZnO}$ nanoparticles on in vitro gas production of some animal and plant protein sources. Kafkas Univ Vet Fak Derg 24

Erwin ES, Marco GJ, Emery EM (1961) Volatile fatty acid analyses of blood and rumen fluid by gas chromatography. J Dairy Sci 44: 17681771 
Eryavuz A, Dehority BA(2009) Effects of supplemental zinc concentration on cellulose digestion and cellulolytic and total bacterial numbers in vitro. Anim Feed Sci Technol 151: 175-183

Froetschel M.A, Martin AC, Amos HE, Evans JJ (1990) Effects of zinc sulfate concentration and feeding frequency on ruminalprotozoal numbers, fermentation patterns and amino acid passage in steers. J Anim Sci 68: 2874-2884

Hook SE, Wright ADG, McBride MBW (2010) Methanogens: methane producers of the rumen and mitigation strategies. Archaea, https:/ /doi.org/10.1155/2010/945785

Hubbert JrF, Cheng E, Burroughs W (1958) Mineral requirement of rumen microorganisms for cellulose digestion in vitro. J Anim Sci 17: 559-568

Karr KJ Dawson KA, Mitchell JrEG(1991) Inhibitory effects of zinc on the growth and proteolytic activity of selected strains of ruminal bacteria. Beef Cattle Res Rep No 337 Univ of Kentucky, Lexington, KY, USA, pp 27

Kathirvelan C, Balakrishnan V (2008) Effect of Supplemental Zinc at 10 ppm on apparent, true digestibility, microbial biomass production and exploring means to overcome ill effects in Cattle. Trends Appl Sci Res 3: 103-108

Mallaki M, Norouzian MA, Khadem AA (2015) Effect of organic zinc supplementation on growth, nutrient utilization, and plasma zinc status in lambs. Turkish J Vet Anim Sci 39: 75-80

Martinez A, Church DC(1970) Effect of various mineral elements on rumen cellulose digestion. J Anim Sci 31: 982-990

Menke KH, Steingass H (1988) Estimation of the energetic feed value obtained from chemical analysis and gas production using rumen fluid. Anim Res Dev 28: 7-55

Nagalakshmi D, Rao KS, Kumari GA, Sridhar K, Satyanarayana M (2016) Comparative evaluation of organic zinc supplementation as proteinate with inorganic zinc in buffalo heifers on health and immunity. Indian J Anim Sci 86: 322-328

Parashuramulu S, NagalakshmiD, Rao DS (2013) Dose response effect of dietary zinc on in vitro digestibility and gas production in sorghum based diet for buffaloes. Indian J Anim Nutr 30: 365-369
Rodriguez BT, Arelovich HM, Villalba JJ, Laborde HE (1995) Dietary supplementation with zinc and manganese improves the efficiency of nitrogen utilization by lambs. J Anim Sci 37: 1233

Sahoo A, Singh B, Bhat TK (2010) Effect of tannins on in vitro ruminal protein degradability of various tree forages. Livest Res Rural Dev 22: $1-8$

Sarkar S, Mohini M, Mondal G, Pandita S, Nampoothiri VM, Gautam M (2018) Effect of supplementing Aegle marmelos leaves on in vitro rumen fermentation and methanogenesis of diets varying in roughage to concentrate ratio. Indian J Anim Res 52: 1180-1184

Sarker NC, Keomanivong F, Borhan M, Rahman S, Swanson K (2018) In vitro evaluation of nano zinc oxide $(\mathrm{nZnO})$ on mitigation of gaseous emissions. J Anim Sci Technol 60: 27

Satter LD, Slyter LL (1974) Effect of ammonia concentration on microbial production in vitro. Br J Nutr 32: 194-201

Shaeffer GL (2006) Evaluation of Basic Zinc Chloride as a Zinc Source for Cattle. MS Thesis. North Carolina State University, Raleigh, NC

Spears JW (2003) Trace mineral bioavailability in ruminants. J Nutr 133:1506-1509

Spears JW, Schlegel P, Seal MC, Lloyd KE (2004) Bioavailability of zinc from zinc sulfate and different organic zinc sources and their effects on ruminal volatile fatty acid proportions. Livest Prod Sci 90: 211217

VanSoest PJ, Robertson JB, Lewis BA (1991) Methods for dietary fiber, neutral detergent fiber, and non-starch polysaccharides in relation to animal nutrition. J Dairy Sci 74: 3583-3597

Vázquez-Armijo JF, Martínez-Tinajero JJ López D, Salem, AFZM, Rojo R (2011) In vitro gas production and dry matter degradability of diets consumed by goats with or without copper and zinc supplementation. Biol Trace Elem Res144: 580-587

Wang RL, Liang JG, Lu L, Zhang LY, Li SF, Luo XG (2013) Effect of zinc source on performance, zinc status, immune response and rumen fermentation of lactating cows. Biol Trace Elem Res 152: 16-24

Zaboli K, Aliarabi H (2013) Effect of different levels of zinc oxide nano particles and zinc oxide on some ruminal parameters by in vitro and in vivo methods. Anim Prod Res 2: 1-13 